\title{
Re-Os Geochronology of the Liuchapo Formation across the Ediacaran-Cambrian Boundary of the Yangtze Block (South China)
}

\author{
Yong Fu $\oplus^{* 1,2}$, Fuliang Wang ${ }^{1,3}$, Chuan Guo ${ }^{1,2}$, Chao $\mathbf{L i}^{4}$, Peng Xia ${ }^{1,2}$ \\ 1. College of Resource and Environmental Engineering, Guizhou University, Guiyang 550025, China \\ 2. Key Laboratory of Karst Georesources and Environment, Ministry of Education, Guizhou University, Guiyang 550025, China \\ 3. Guizhou Geological Environment Monitoring Institute, Guizhou 550081, China \\ 4. National Research Center for Geoanalysis, Chinese Academy of Geological Sciences, Beijing 100037, China \\ (D) Yong Fu: https://orcid.org/0000-0002-3539-4914
}

\begin{abstract}
The Ediacaran-Cambrian (E-C) succession in South China records remarkable oceanic, biological and geochemical variations, but it was not well defined geochronologically, which hinders the interpretation of the spatio-temporal seawater chemical architecture during the time $\mathbf{E}-\mathrm{C}$ interval. This study presents two Re-Os isochron ages of 520.2 \pm 6.1 and $561.7 \pm 8.5$ Ma for the barite-rich black shales from the top Liuchapo and Doushantuo formations respectively in Tianzhu County, Guizhou Province. In combination with existing age data, the two new Re-Os isochron ages suggest that the Liuchapo Formation was deposited between 550 and 520 Ma. Moreover, like the polymetallic Ni-MoPGE layers of shelf margin (or platform) facies and V-rich horizons of transitional (or shelf slope) to deep-water facies, the barite deposits were likely formed due to differential mineralization. The timing offset likely resulted from differential elemental concentration related to certain local factors (i.e., hydrothermal fluids, seawater redox and biological activity). The isochron-derived initial ${ }^{187} \mathrm{Os}^{1188} \mathrm{Os}$ ratios of the top Liuchapo Formation $(0.902 \pm \mathbf{0 . 0 4 8})$ and the Doushantuo Formation $(0.740 \pm 0.042)$ fall within the range of continental weathering flux (1.54) and oceanic crust (0.126), implying the involvement of marine hydrothermal fluids. Moreover, their difference of initial ${ }^{187} \mathrm{Os}^{1188} \mathrm{Os}$ ratios may reflect variations of continental weathering intensity and uplift magnitude.
\end{abstract}

KEY WORDS: geochemistry, Ediacaran-Cambrian, initial ${ }^{187} \mathrm{Os}^{1188} \mathrm{Os}$, Liuchapo Formation, Re-Os isotope, Yangtze Block.

\section{INTRODUCTION}

The Ediacaran-Cambrian (E-C) transition, a critical time interval in Earth history, witnessed dramatic changes in global tectonic configuration and oceanic environment, e.g., the assembly and breakup of Rodinia supercontinent (Zhao et al., 2018), long-lasting ocean anoxia (e.g., Sun et al., 2021; Huang et al., 2019; Feng et al., 2014), and extensive seafloor hydrothermal activities and mineralization along platform margin (e.g., Liu et al., 2021; Han et al., 2017; Chen et al., 2009). Subsequently, metazoans appeared and radiated, in the course of significant changes in oceanic chemical environments and the extinction of Ediacaran fauna (e.g., Zhou et al., 2019; Zhu et al., 2019; Erwin et al., 2011). In South China, the EC successions were deposited continuously and well preserved notably in the deep-water setting, which could serve as an important win-

*Corresponding author: byez1225@126.com

(C) The Authors 2022. This article is published with open access at Springerlink.com

Manuscript received December 23, 2020.

Manuscript accepted April 20, 2021. dow to understand the aforementioned major geologic processes. Numerous studies mainly focus on the deep-water shaledominated environments or the correlative shallow-water carbonate platform. The deep-water silicious- and/or argillaceousdominated environments, however, were paid little attention to. In contrast to shallow-water environments, the deep-water environments are characterized by more continuous sedimentation that is fundamental for the construction of age framework. Additionally, the precise chronostratigraphic framework of deepwater environments and correlation between deep-water and shallow-water sedimentary sequences are of significant importance to elucidate the coupling relationship between global tectonic evolution, variations in geological environment, fauna evolution and development of ore deposits during the E-C transition.

In the Yangtze Block, the Lower Cambrian polymetallic Ni-Mo-PGE layer was considered as the marker horizon for the boundary between Ediacaran and Cambrian (e.g., Shi et al., 2021; Jiang et al., 2009; Li et al., 2003; Mao et al., 2002). More recently, the zircon $\mathrm{U}-\mathrm{Pb}$ ages and $\mathrm{Re}-\mathrm{Os}$ ages derived from the Liuchapo Formation and the base of the overlying Niutitang Formation of deep-water settings, however, suggested that the E-C boundary should be placed within the Liuchapo

Fu, Y., Wang, F. L., Guo, C., et al., 2022. Re-Os Geochronology of the Liuchapo Formation across the Ediacaran-Cambrian Boundary of the Yangtze Block (South China). Journal of Earth Science, 33(1): 25-35. https://doi.org/10.1007/s12583-021-1473-4. http:// en.earth-science.net 
Formation (e.g., Wang W et al., 2020; Yang et al., 2017; Fu et al., 2016; Chen et al., 2015; Wang X Q et al., 2012; Xu et al., 2011). Condon et al. (2005) obtained a high-precision zircon U-Pb age of $551.1 \pm 0.7 \mathrm{Ma}$ from the top of the Miaohe Member of the Doushantuo Formation at the Jiuqunao of western Hubei Province, which was considered as the terminal age of the Doushantuo Formation or the onset age of the overlying Dengying Formation. A few researchers, however, even suggested that the Miaohe Member should be assigned to the Dengying Formation and it was supposedly deposited earlier than $550 \mathrm{Ma}$ (e.g., An et al., 2015). Due to limited and discontinuous distribution of volcanic tuffs, the precise age framework of the Liuchapo Formation is still not well established.

On the other hand, the Re-Os dating can also provide direct age constraints on sedimentary rocks rich in organic matter (e.g., black shale). Previous studies have shown that the Re-Os ages of the organic-rich black shales are generally consistent with the high-precision zircon $\mathrm{U}-\mathrm{Pb}$ ages within errors (e.g., Rotich et al., 2020; Tripathy and Singh, 2015; Rooney et al., 2014; Yang et al., 2009). Meanwhile, the initial ${ }^{187} \mathrm{Os} /{ }^{188} \mathrm{Os}$ ratios can constrain the temporal variations in ${ }^{187} \mathrm{Os} /{ }^{188} \mathrm{Os}$ ratios of coeval seawater, thereby tracing the sources of Os (continental or volcanic fluxes) (e.g., Liu et al., 2020; Matsumoto et al., 2020; Tripathy and Singh, 2015; Yang et al., 2009; Yamashita et al., 2007; Hannah et al., 2004). In this study, the Re-Os isochron dating method was applied to constrain the depositional ages of the Liuchapo Formation in the Tianzhu area of Guizhou Province and paleoenvironmental/paleoclimatic information of the study area during the $\mathrm{E}-\mathrm{C}$ transition.

\section{GEOLOGICAL SETTING}

The South China Block was created by the amalgamation of the Yangtze and Cathaysia blocks along the Jiangnan Orogen during the Early Neoproterozoic (Zhao et al., 2018; Charvet, 2013). Due to intensive continental rifting of the South China since ca. $820 \mathrm{Ma}$, rift basins were developed within or along the eastern margin of the Yangtze Block, leading to the differential sedimentation across the basin strike (i.e., from shallow platform to deep-water settings) (e.g., Jiang et al., 2011; Wang and Li, 2003). During the Late Ediacaran, the shallowwater platform was mainly occupied by carbonate (mainly dolomite) rocks of the Dengying Formation, which passed basin ward rapidly into bedded cherts of the Liuchapo Formation in the deep-water settings (i.e., slope to basin) (e.g., Ding et al., 2019; Jiang et al., 2003). Up section, the phosphatic nodulebearing or polymetallic Ni-Mo-PGE layers in the basal Niutitang Formation deposited on antecedent carbonate platform margin pinch out basin ward and grade gradually to V- or Baenriched shale-chert assemblages of equivalent strata (e.g., Fu et al., 2016; Wang Y et al., 2012).

The studied borehole (Zk205) is located at the Yundong barite mine of the Tianzhu County of eastern Guizhou Province. Paleogeographically, it was situated in the slope to basinal environments. The recovered core, in ascending order, comprises Doushantuo, Liuchapo and Jiumenchong formations (Fig. 1). The Doushantuo Formation, with a thickness of 40.55 $\mathrm{m}$, was not penetrated completely. This formation, overlain conformably by the Liuchapo Formation, is mainly character- ized by light- to dark-gray dolomites and argillaceous dolomites in lithology, grading upward into interbedded light-gray dolomites and black shale. The Liuchapo Formation, $45 \mathrm{~m}$ thick, is overlain by the Lower Cambrian Jiumenchong Formation and is primarily represented by dark and dark-gray chert, which passes into barite-enrich shale of $2.4 \mathrm{~m}$ in the uppermost part. The barite ores display various shapes (e.g., nodular, lenticular and banded) and an increase in ore grade.

\section{MATERIALS AND METHODS}

The samples were sampled at $10-15 \mathrm{~cm}$ spacing intervals from the fresh and un-weathered rocks of borehole Zk205 in Yundong mine site of Tianzhu County, Guizhou Province (Fig. 1c). Five samples (Zk205-83-Zk205-87) were sampled from the black shales within the barite ore layer of the top Liuchapo Formation to define its termination age. In view of the dominance of $4.1 \mathrm{~m}$ chert in the basal Liuchapo Formation, which is not suitable for Re-Os dating, four samples of black shales (Zk205-3-Zk205-6; Fig. 2) in the Member IV of the underlying Doushantuo Formation were alternatively selected to constrain the depositional age of the basal Liuchapo Formation.

About $100 \mathrm{~g}$ of fresh broken rock samples was washed by alcohol first and dried $12 \mathrm{~h}$ in an oven at $60^{\circ} \mathrm{C}$. These samples were further crushed into 200 mesh in size within the agate mortar. The chemical separation follows the procedure described by Li et al. (2010a) and Fu et al. (2016). Approximately $100 \mathrm{mg}$ of sample powders was reacted with a mixture of 3 $\mathrm{mL}$ of $10 \mathrm{M} \mathrm{HCl}$ and $5 \mathrm{~mL}$ of $16 \mathrm{M} \mathrm{HNO}_{3}$ in a Carius tube, with addition of a mixture spike solution of ${ }^{190} \mathrm{Os}$ and ${ }^{185} \mathrm{Re}$ (Oak Ridge National Laboratory). During the reaction process, the bottom of the tube was frozen to $-50--80{ }^{\circ} \mathrm{C}$ in an ethanolliquid nitrogen slush. When the reaction solution was completely frozen, the tube was first sealed via an oxygen-propane torch and then placed in a stainless steel jacket. After heated for $24 \mathrm{~h}$ at $200{ }^{\circ} \mathrm{C}$, Os was transformed into $\mathrm{OsO}_{4}$. After cooling, the tube was frozen again and the reaction solution was transferred into a distillation flask with the addition of $30 \mathrm{~mL}$ of deionized water. Osmium was distilled by heating for 50 min at $100-105{ }^{\circ} \mathrm{C}$ and collected in $10 \mathrm{~mL}$ of deionized water. The residual solution was converted into a Teflon beaker and heated on a hotplate at $120{ }^{\circ} \mathrm{C}$. The residual was reacted with 1 $\mathrm{mL}$ of deionized water and then was dried up on hotplate twice. Ten $\mathrm{mL}$ of $5 \mathrm{M} \mathrm{NaOH}$ solution was added into the Teflon beaker to obtain alkaline conditions. Ten $\mathrm{mL}$ of acetone was applied to extract Re in a Teflon separation funnel. And the Re-bearing acetone was washed twice with $2 \mathrm{~mL}$ of $5 \mathrm{M}$ $\mathrm{NaOH}$ for $2 \mathrm{~min}$ and heated at $50{ }^{\circ} \mathrm{C}$ to remove acetone. The residual was dissolved with $2 \% \mathrm{HNO}_{3}$. The Re content and Os isotope were measured on a high resolution inductively coupled plasma mass spectrometry (HR-ICP-MS, Element 2) in the Re-Os laboratory, National Research Center for Geoanalysis, Chinese Academy of Geological Sciences. The Re-Os isochron ages were obtained via the linear regression analyses using the Isoplot software.

\section{RESULTS}

The Re-Os abundances and isotope data for the nine samples of the borehole Zk205 in the Yundong mine site of the 
Tianzhu County are shown in Table 1. The samples (Zk205-83Zk205-87) of barite-bearing black shales from the top part the Liuchapo Formation yield Re concentration of $90.73 \mathrm{ppb}$ to $430.47 \mathrm{ppb}$ (average $188.68 \mathrm{ppb}$ ), Os abundance of $0.85 \mathrm{ppb}$ to $3.78 \mathrm{ppb}$ (average $1.77 \mathrm{ppb}$ ), and ${ }^{187} \mathrm{Os}$ concentration of 0.59 ppb to $2.67 \mathrm{ppb}$ (average $1.24 \mathrm{ppb}$ ). The ${ }^{187} \mathrm{Re} /{ }^{188} \mathrm{Os}$ and
${ }^{187} \mathrm{Os} /{ }^{188} \mathrm{Os}$ ratios vary from 275.81 to 779.96 (average 547.32) and from 3.30 to 7.69 (average 5.67), respectively. Four samples (Zk205-3-Zk205-6) of black shales from the Member IV of the underlying Doushantuo Formation have Re concentration of $25.98 \mathrm{ppb}$ to $219.5 \mathrm{ppb}$ (average $121.53 \mathrm{ppb}$ ), Os abundance of $0.63 \mathrm{ppb}$ to $2.33 \mathrm{ppb}$ (average $1.51 \mathrm{ppb}$ ), and ${ }^{187} \mathrm{Os}$
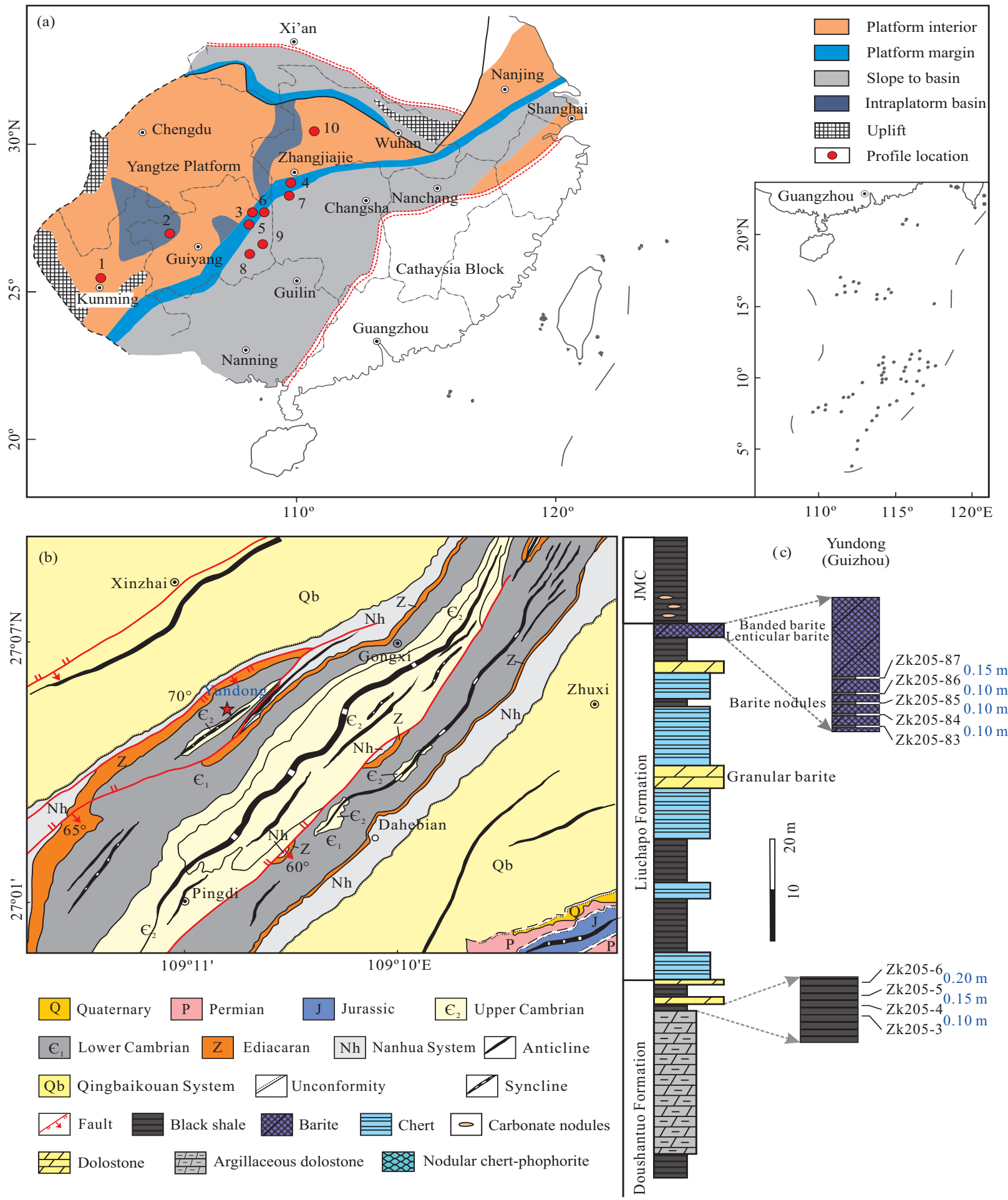

Figure 1. (a) Palaeogeography of the earliest Cambrian in the Yangtze Platform, South China (modified after the national standard map of No. GS(2019)1676 and Chen et al., 2009). (b) Geologic sketch map of Yundong Section in Tianzhu, Guizhou Province. (c) Upper Ediacaran-Lower Cambrian stratigraphic column in the Yundong Section, Tianzhu, Guizhou Province. Reference sections: 1. Meishuchun; 2. Songling; 3. Taoying; 4. Ganziping; 5 . Pingyin; 6 . Bahuang; 7. Longbizui; 8. Yangtou; 9. Yundong; 10. Jiuqunao. The marked numbers (blue) on the right of the sample numbers indicate the sampling spacing. 


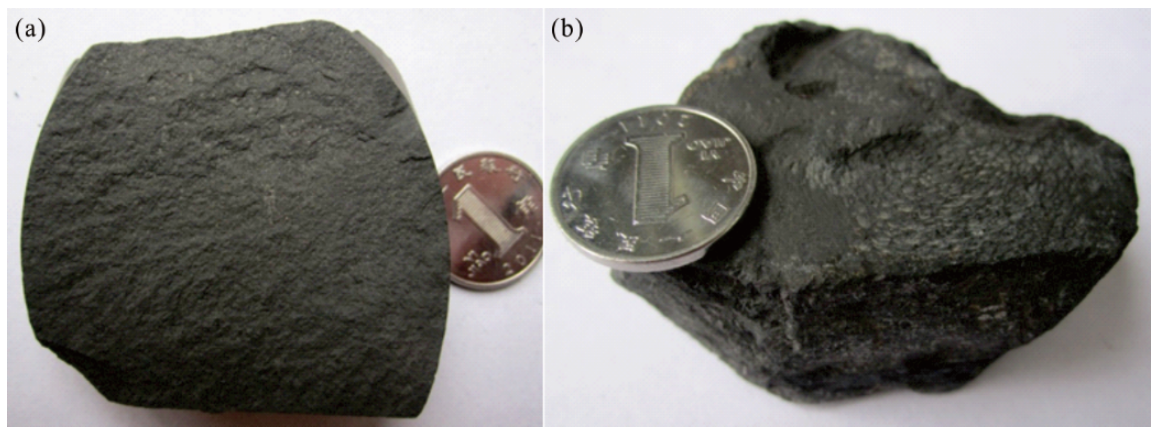

Figure 2. General features of samples Zk205-3 (a) and Zk205-5 (b) from the top part of Doushantuo Formation in the Yundong Section.

concentration of $0.21 \mathrm{ppb}$ to $1.52 \mathrm{ppb}$ (average $0.86 \mathrm{ppb}$ ). The ${ }^{187} \mathrm{Re} /{ }^{188} \mathrm{Os}$ and ${ }^{187} \mathrm{Os} /{ }^{188} \mathrm{Os}$ values vary from 200.08 to 454.28 (average 345.48) and from 2.62 to 5.00 (average 3.99), respectively. The samples of barite-bearing black shales of the top part the Liuchapo Formation yield Re-Os isochron age of $520.2 \pm 6.1 \mathrm{Ma}(2 \sigma$ uncertainty, $n=6, \mathrm{MSWD}=0.19)$, with initial ${ }^{187} \mathrm{Os} /{ }^{188} \mathrm{Os}$ values of $0.902 \pm 0.048$ (Fig. 3). Four samples of black shales of the Member IV of the underlying Doushantuo Formation have Re-Os isochron age of $561.7 \pm$ 8.5 Ma ( $\sigma \sigma$ uncertainty, $n=4$, MSWD $=1.11)$, with initial ${ }^{187} \mathrm{Os} /{ }^{188} \mathrm{Os}$ values of $0.740 \pm 0.042$ (Fig. 3).

\section{DISCUSSION}

\subsection{Geochronological Framework and Regional Strati-} graphic Correlation

Due to the lack of correlatable fossils, the Liuchapo Formation, overlying the Doushantuo Formation, was previously considered as the time-equivalent succession of the Dengying Formation of the shallow-water settings on the basis of the correlation of the lithologies and their stacking sequence (e.g., Wang Y et al., 2012). Recently, Chen et al. (2015) reported two weighted-mean $\mathrm{U}-\mathrm{Pb}$ ages of $542.1 \pm 5.0 \mathrm{Ma}$ (Ganziping, Hunan Province) and 542.6 $\pm 3.7 \mathrm{Ma}$ (Bahuang, Guizhou Province) for the basal and Mid-Upper Liuchapo Formation in slope-basinal settings, respectively (Fig. 4; Table 2). Yang et al. (2017) obtained a new CA-ID-TIMS zircon U-Pb age of $545.76 \pm 0.66 \mathrm{Ma}$ for the Lower Liuchapo Formation in deepwater setting (Longbizui Section, western Hunan Province). Recently, Wang et al. (2020) presented two CA-ID-TIMS zircon U-Pb ages of $536.40 \pm 0.47$ and $541.48 \pm 0.46 \mathrm{Ma}$ for the top Liuchapo Formation (1.2 and $2.4 \mathrm{~m}$ under top, respective- ly) in deep-water setting (Pingyin Section, Guizhou Province) (Table 2). Together with the existing data, the newly obtained ages suggest that the deposition of the Liuchapo Formation in transitional and deep-water facies was most likely diachronous (e.g., Wang et al., 2020; Fu et al., 2016; Chen et al., 2015). The deposition of the Liuchapo Formation firstly took place in deep-water environments and expanded into shallower-water environments (Fig. 4) (e.g., Chen et al., 2009). In contrast, the depositional ages of the overlying Lower Cambrian Niutitang Formation have attracted more attentions, which can also provide indirect constraint on the upper limit of depositional age of the Liuchapo Formation. A U-Pb SHRIMP age of $522.7 \pm$ 4.9 Ma was obtained by Wang Y et al. (2012) from a tuffaceous bed of the basal Niutitang Formation (below the phosphatic nodules) in the transitional facies of Taoying (Guizhou Province). Two SIMS zircon U-Pb ages of $522.3 \pm 5.3$ and $522.3 \pm 3.7 \mathrm{Ma}$ were reported by Chen et al. (2015) from the basal Niutitang Formation in the transitional facies of Panmen and Bahuang (Guizhou Province). In addition, some economic geologists also gained the mineralization timing of polymetallic Ni-Mo layers in the basal Niutitang Formation via the ReOs isochron dating method. For example, a composite Re-Os isochron age of $521 \pm 5 \mathrm{Ma}$ was obtained by Xu et al. (2011) from sulfide layer in the basal Niutitang Formation in the antecedent platform facies of Songling and Niuchang (Guizhou Province) and Sancha (Hunan Province). A Re-Os isochron age $(520.3 \pm 9.1 \mathrm{Ma})$ of V-enriched black shale of the transitional facies was obtained by $\mathrm{Fu}$ et al. (2016) from Bahuang (Guizhou Province). Taking the measure errors into account, the high-precision zircon $\mathrm{U}-\mathrm{Pb}$ ages and $\mathrm{Re}-\mathrm{Os}$ isochron ages of the Lower Cambrian Niutitang Formation indicate that its depo-

Table 1 Re and Os concentrations and isotopic data for the Liuchapo and Doushantuo formations of Zk205 in the Yundong mine site,

Tianzhu County, Guizhou

\begin{tabular}{lccccccc}
\hline Sample No. & Formation & Lithology & Re $(\mathrm{ppb})$ & Os $(\mathrm{ppb})$ & ${ }^{187} \mathrm{Os}(\mathrm{ppb})$ & ${ }^{187} \mathrm{Re} /{ }^{188} \mathrm{Os}$ \\
\hline ZK205-3 & Doushantuo & Black shale & $219.45 \pm 1.6$ & $2.33 \pm 0.017$ & $1.52 \pm 0.011$ & $454.28 \pm 4.60$ & $5.00 \pm 0.007$ \\
ZK205-4 & Doushantuo & Black shale & $164.81 \pm 1.2$ & $1.80 \pm 0.014$ & $1.15 \pm 0.009$ & $440.60 \pm 4.45$ & $4.87 \pm 0.007$ \\
ZK205-5 & Doushantuo & Black shale & $75.89 \pm 0.6$ & $1.28 \pm 0.010$ & $0.57 \pm 0.004$ & $286.96 \pm 2.90$ & $3.46 \pm 0.005$ \\
ZK205-6 & Doushantuo & Black shale & $25.98 \pm 0.2$ & $0.63 \pm 0.005$ & $0.21 \pm 0.001$ & $200.08 \pm 2.02$ & $2.62 \pm 0.004$ \\
ZK205-83 & Liuchapo & Black shale & $216.49 \pm 1.6$ & $3.78 \pm 0.028$ & $1.63 \pm 0.012$ & $275.81 \pm 2.79$ & $3.30 \pm 0.005$ \\
ZK205-84 & Liuchapo & Black shale & $148.46 \pm 1.1$ & $1.22 \pm 0.009$ & $0.96 \pm 0.007$ & $585.52 \pm 5.91$ & $6.00 \pm 0.009$ \\
ZK205-85 & Liuchapo & Black shale & $90.73 \pm 0.1$ & $0.87 \pm 0.007$ & $0.59 \pm 0.005$ & $506.68 \pm 5.13$ & $5.29 \pm 0.009$ \\
ZK205-86 & Liuchapo & Black shale & $430.47 \pm 3.2$ & $2.66 \pm 0.020$ & $2.67 \pm 0.020$ & $779.96 \pm 7.87$ & $7.69 \pm 0.011$ \\
ZK205-87 & Liuchapo & Black shale & $96.48 \pm 0.7$ & $0.85 \pm 0.006$ & $0.62 \pm 0.005$ & $547.43 \pm 5.52$ & $5.67 \pm 0.008$ \\
\hline
\end{tabular}



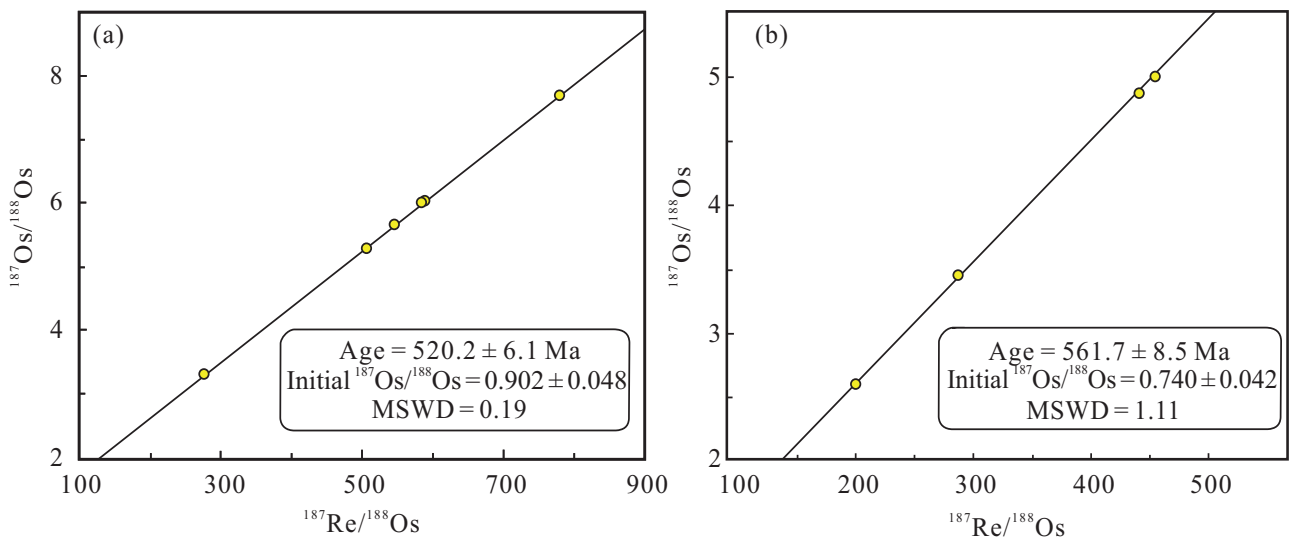

Figure 3. (a) Re-Os isochron diagrams for the samples from the top part of Liuchapo Formation in the Yundong Section; (b) Re-Os isochron diagrams for the samples from the top part of Doushantuo Formation in the Yundong Section.

sitional age should commence at ca. $520 \mathrm{Ma}$ (Fig. 4). This is approximately in accordance with the Re-Os isochron age $(520.2 \pm 6.1 \mathrm{Ma})$ of the barite-rich black shale of the topmost part of the underlying Liuchapo Formation. Additionally, these ages also define the development timing of the polymetallic $\mathrm{Ni}$ Mo-PGE ore layers and V-rich layer of the Niutitang Formation in the platformal (or shelfal) facies and the transitional facies respectively and the barite ore of the Liuchapo Formation. Considering the stratigraphic position of the barite ore of the Liuchapo Formation which is located below the polymetallic layers or correlative horizons of the basal Niutitang Formation (Fig. 4), the large-scale mineralization of barite deposits may have taken place earlier than the deposition of the polymetallic Ni-Mo-PGE and/or V-enriched layers of the basal Niutitang Formation. The offset in timing probably resulted from differential elemental concentration most likely related to the certain local factors (i.e., hydrothermal fluids, seawater redox and biological activity) (e.g., Shi et al., 2021; Han et al., 2017; Chen et al., 2009). In addition, the barite deposits initially occur in the middle-upper part of the Liuchapo Formation, and show an improvement in ore grade and a decreasing-upward thickness of chert, indicating the localized variations of paleogeography and seawater chemistry (e.g., Li et al., 2020, 2010b; Huang et al., 2019). Hence, the Re-Os isochron age (520.2 $\pm 6.1 \mathrm{Ma})$ of the barite-rich black shale of the top part of the Liuchapo Formation provides a geochronologic link for the construction of spatio-temporal (from platform through transitional to deepwater facies) evolution of paleo-ocean chemistry during the E$\mathrm{C}$ transition.

The correlation criteria of E-C boundary across South China have not been established hitherto. Zhu et al. (2019) suggested that under the condition of biostratigraphic criteria having not been erected, the E-C boundary can be placed at the base of the basal Cambrian negative carbon isotope excursion (BACE), i.e., the transitional point from the terminal Ediacaran positive isotope plateau (EPIP) to BACE excursion. The BACE excursion is considered as a feasible method to determine the precision of high-precision zircon $\mathrm{U}-\mathrm{Pb}$ ages of E-C boundary (e.g., Huang et al., 2020; Wang et al., 2020; Yang et al., 2017). In Yunnan Province (China), volcanic ash beds at the base of the BACE excursion from several E-C transitional intervals yield zircon ages of 540.7-539.6 Ma (Zhu et al., 2017), indicating that the ages of the E-C boundary should be younger than 539.6 Ma (Zhu et al., 2019). Together with the high-precision zircon ages (536.3 $\pm 5.5 \mathrm{Ma}$, Chen et al., 2009; $542.6 \pm 3.7 \mathrm{Ma}$, Chen et al., 2015; $545.76 \pm 0.66 \mathrm{Ma}$, Yang et al., 2017) from the internal Liuchapo Formation of the transitional and deep-water facies, the newly obtained Re-Os age $(520.2 \pm 6.1 \mathrm{Ma})$ from the barite-rich black shale of the top part of the Liuchapo Formation indicates that the E-C boundary should be placed within the Liuchapo Formation (Fig. 4). Therefore, the sedimentary sequences of the Liuchapo Formation can provide an important window to better understand the geological events during the E-C transition. A SHRIMP U-Pb age of $550 \pm 3 \mathrm{Ma}$ was obtained for the beginning age of the Liuchapo Formation by Zhou et al. (2018) from a K-bentonite in the basal Liuchapo Formation of Fanglong Section (geographically located in slope), Guizhou Province. Recently, a LA-ICP-MS zircon U-Pb age of 550.6 \pm 3.3 Ma was obtained by Chen et al. (2020) from the tuff in the basal Liuchapo Formation at the Yangtou Section, Guizhou Province, which is consistent with the age $(551.1 \pm 0.7 \mathrm{Ma})$ of the top part of the Miaohe Member in the Three Gorges. These ages attest to the initial depositional age of approximately $550 \mathrm{Ma}$ for the Liuchapo Formation. A Re-Os age of $561.7 \pm 8.5 \mathrm{Ma}$ was obtained in this study from the black shale of the top part of the Doushantuo Formation, the sampling position of which was $2.2 \mathrm{~m}$ below the base of the Liuchapo Formation. This age is $10 \mathrm{Ma}$ older than the previously reported high-precision zircon $\mathrm{U}-\mathrm{Pb}$ age $(551.1 \pm 0.7 \mathrm{Ma}$; Condon et al., 2005) of the top part of the Doushantuo Formation. The average sedimentation rate of the $2.2 \mathrm{~m}$ interval is calculated to approximately be $0.22 \mathrm{~mm} / \mathrm{ka}$. The calculated sedimentation rate is lower than the reported values $(0.3-0.4 \mathrm{~mm} / \mathrm{ka})$ that was calculated for the $12 \mathrm{~m}$ interval below the E-C boundary (Zhu et al., 2013) and those ( 2 or $1 \mathrm{~mm} / \mathrm{ka}$ ) estimated for other condensed black shales that were similarly deposited in stratified water column under euxinic conditions (Finlay et al., 2010; Stein, 1990). The discrepancy is possibly ascribed to the development of one or several hiatuses in this interval, the possibility of which is most likely ruled out by the deep-water setting of borehole Zk205 in Yundong mine site. Alternatively, the depositional age of the sam- 


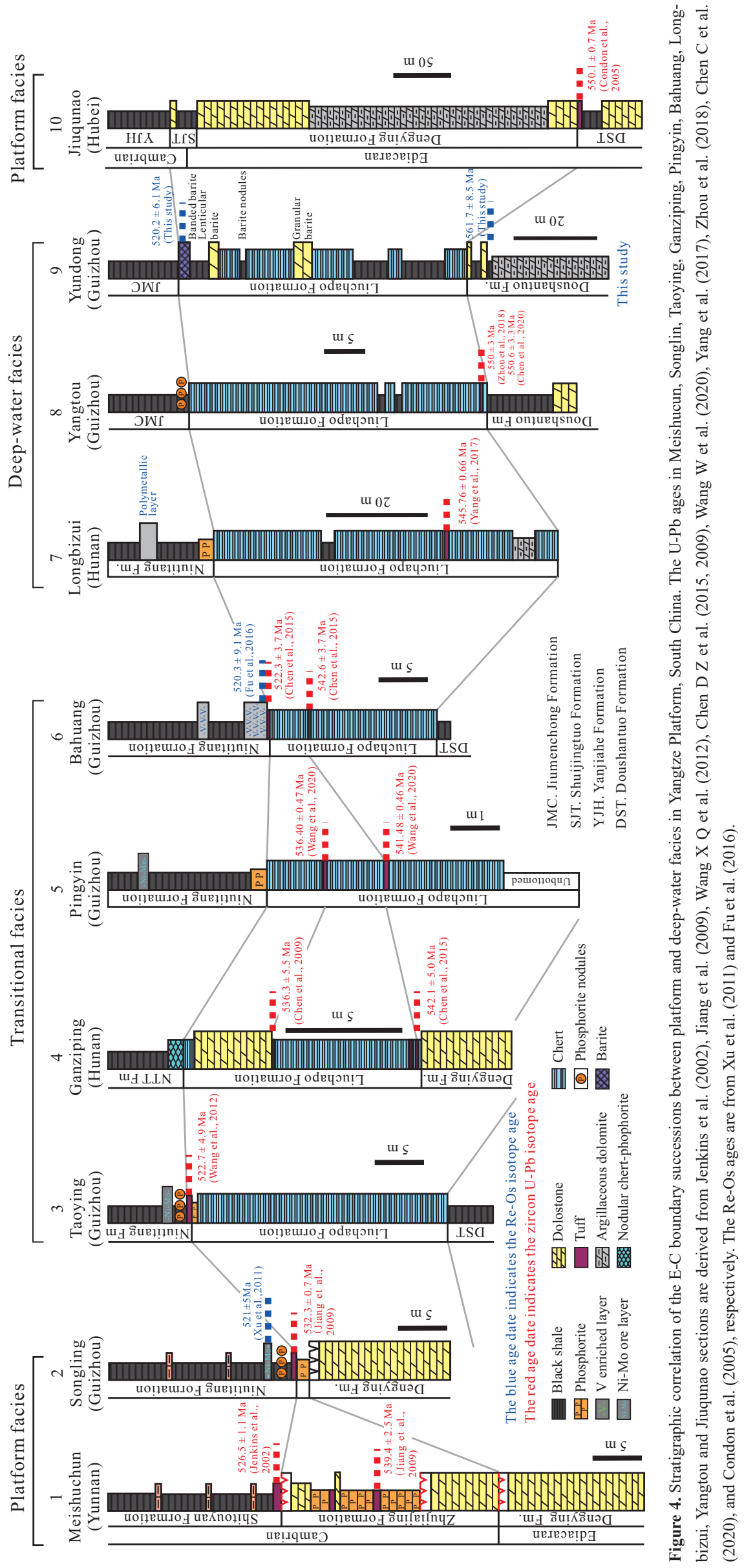




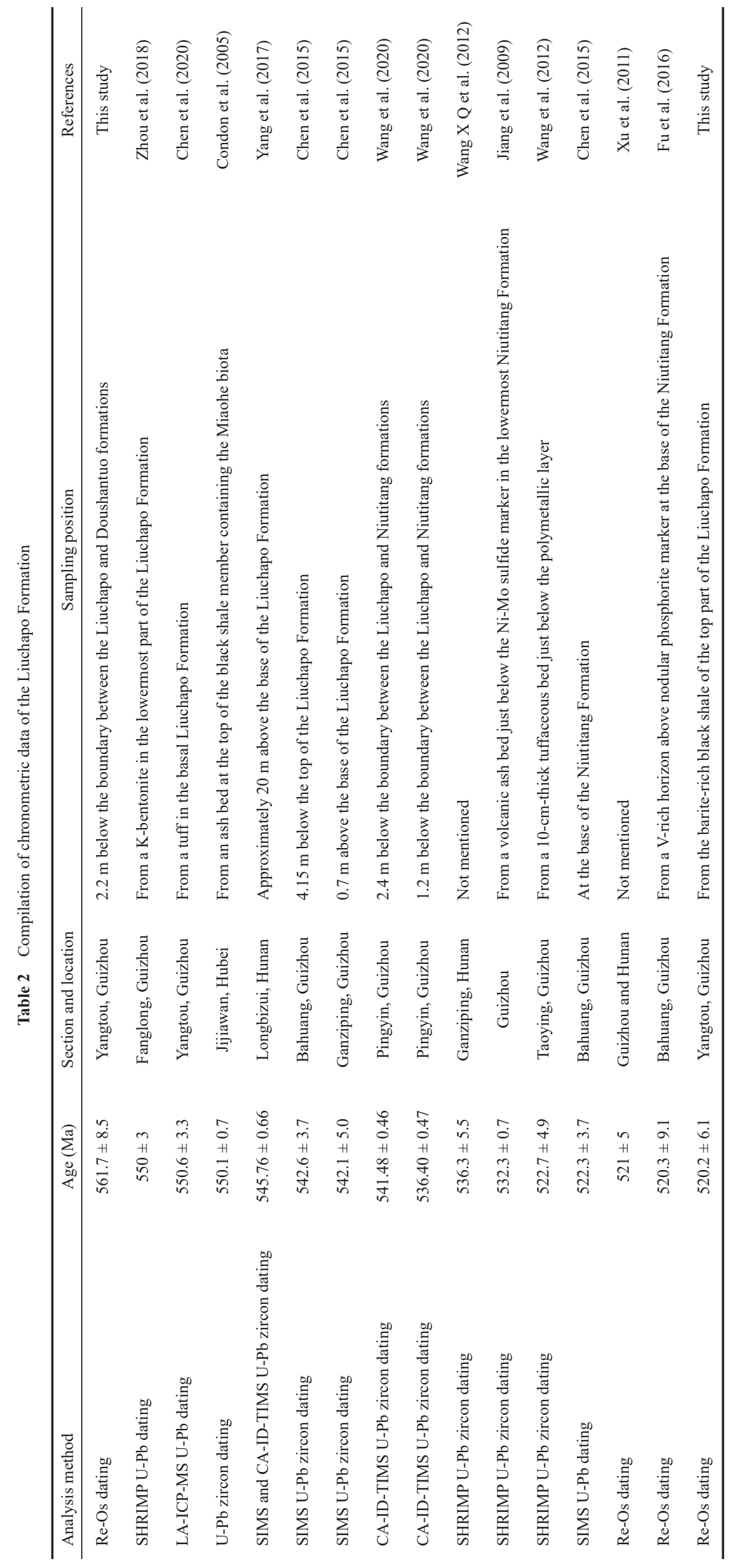


pled interval is younger than the Re-Os age of $561.7 \pm 8.5 \mathrm{Ma}$. Taking $0.3-2 \mathrm{~mm} / \mathrm{ka}$ as the sedimentation rate of the sampled interval, its calculated depositional ages range from 552.2 to 558.4 $\mathrm{Ma}$, which is comparable to the newly-obtained Re-Os age of $561.7 \pm 8.5 \mathrm{Ma}$ within error. Hence, it also attests to the lower limit ( $550 \mathrm{Ma})$ of depositional age of the Liuchapo Formation.

\subsection{Implications for Os Isotopic Composition of Ediacaran- Cambrian Seawater}

The mass balance of Os in seawater is primarily influenced by the combination of radiogenic contribution from riverine-delivered continental weathering $\left({ }^{187} \mathrm{Os} /{ }^{188} \mathrm{Os}=1.54\right)$ and unradiogenic contribution from alteration of oceanic crust $\left({ }^{187} \mathrm{Os} /{ }^{188} \mathrm{Os}=0.126\right)$ and cosmic dusts $\left({ }^{187} \mathrm{Os} /{ }^{188} \mathrm{Os}=0.126\right)$ (Cohen, 2004; Levasseur et al., 1999). Since the cosmic dust-derived Os only accounts for $\sim 14 \%$ of the contribution of the unradiogenic component, the riverine-derived and oceanic crust sources are considered as the major contribution to the Os composition of seawater (e.g., McDaniel et al., 2004; Levasseur et al., 1999). Hence, the secular fluctuations of the initial ${ }^{187} \mathrm{Os} /{ }^{188} \mathrm{Os}$ values of seawater can be utilized to trace the variations of Os input that is primarily related by glacioeustatic sealevel fluctuations, tectonics and paleoclimatic changes (e.g., Tripathy and Singh, 2015; McDaniel et al., 2004; PeuckerEhrenbrink and Ravizza, 2000). The present-day seawater has ${ }^{187} \mathrm{Os} /{ }^{188} \mathrm{Os}$ values of $\sim 1.0$, pointing to the main contribution of riverine-derived weathering of radiogenic crustal rocks under oxic conditions (e.g., Peucker-Ehrenbrink and Ravizza, 2000; Cohen et al., 1999; Sharma and Wasserburg, 1997). In contrast, the estimated ${ }^{187} \mathrm{Os} /{ }^{188} \mathrm{Os}$ values $(0.1-0.15)$ of the Archean seawater are much lower, denoting the dominance of oceanic crustderived Os under anoxic condition (e.g., Yang et al., 2009; Hannah et al., 2004). Although the conversion of seawater Os from oceanic crust- to riverine-dominated flux is still poorly constrained, it was believed to likely take place during the Mesoproterozoic to Neoproterozoic (Peucker-Ehrenbrink and Ravizza, 2000). And the increase in seawater Os isotopic composition has been interpreted as a response to influx derived from enhanced weathering of continental crust rocks under oxic conditions, which was roughly associated with the amlgamation of of Rodinia supercontinent (e.g., Turgeon et al., 2007; PeuckerEhrenbrink and Ravizza, 2000; Sharma and Wasserburg, 1997).

Due to the hydrogenous origin of majority of the Os in marine organic-rich sedimentary rocks, the initial ${ }^{187} \mathrm{Os} /{ }^{188} \mathrm{Os}$ values from their Re-Os isochron regressions are commonly applied to define osmium isotopic composition of the coeval seawater (Rooney et al., 2014; Cohen, 2004; Cohen et al., 1999). In addition, the residence time of Os in the modern ocean is $\sim 10^{4}$ year (Peucker-Ehrenbrink and Ravizza, 2000; Levasseur et al., 1999; Oxburgh, 1998; Sharma and Wasserburg, 1997), which is much shorter than that $(\sim 2 \mathrm{Ma})$ of strontium $(\mathrm{Sr})$ (Kendall et al., 2006; Cohen et al., 1999). This attribute permits Os as a better tracer to record the subtle changes in seawater chemistry than the $\mathrm{Sr}$ isotope (Cohen, 2004; Ravizza and Peucker-Ehrenbrink, 2003). Moreover, only in case of sedimentary basin being well connected to the open ocean, the initial ${ }^{187} \mathrm{Os} /{ }^{188} \mathrm{Os}$ ratios of organic-rich sedimentary rocks can be reasonably utilized to reflect the Os isotopic compositions of glob- al seawater (e.g., Fu et al., 2016; Zhu et al., 2013; Cohen, 2004). Previous studies have suggested that the study area was located in an open-marine setting during the sedimentation of the Liuchapo and Doushantuo formations (e.g., Ding et al., 2019; Jiang et al., 2011). Hence, the initial ${ }^{187} \mathrm{Os} /{ }^{188} \mathrm{Os}$ ratios of organic-rich black shales of the formations can be applied to trace the Os isotopic compositions of global seawater. The initial ${ }^{187} \mathrm{Os} /{ }^{188} \mathrm{Os}$ value $(0.740 \pm 0.042)$ of black shale of top part (Member IV) of the Doushantuo Formation falls within the range between more radiogenic $(\sim 1.54)$ and unradiogenic $(\sim 0.126)$ Os isotopic ratios and is also lower than the initial ${ }^{187} \mathrm{Os} /{ }^{188} \mathrm{Os}$ ratio $(\sim 1.0)$ of modern normal seawater (Fig. 5), pointing to that the less radiogenic Os derived from alteration of oceanic crust were incorporated into the sedimentation of black shale. In addition, the initial ${ }^{187} \mathrm{Os} /{ }^{188} \mathrm{Os}$ value of the Member IV of the Doushantuo Formation is below the reported values (0.79-0.91; Zhu et al., 2013 and $1.22 \pm 0.26$; Kendall et al., 2009) of corresponding horizons in the Three Gorges area (Hubei Province). This discrepancy is likely ascribed to the different paleogeographic locations of the two localities during the deposition of the Member IV of the Doushantuo Formation (e.g., Dickson et al., 2015; Du Vivier et al., 2014). In contrast to the Yundong area (Guizhou Province), the Three Gorges area was likely situated more proximal to paleocoastline and landmass, which was influenced by higher influx of radiogenic riverine-delivered Os from the weathering of continental crust. In addition, the initial ${ }^{187} \mathrm{Os} /{ }^{188} \mathrm{Os}$ value $(0.902 \pm 0.048)$ of the top part of the Liuchapo Formation is comparable with those of contemporaneous polymetallic Ni-Mo layers $(0.87 \pm 0.07, \mathrm{Xu}$ et al., 2011; $0.90 \pm 0.09$, Fu et al., 2016) and black shale $(0.83$ \pm 0.02 ; Wei et al., 2018). All ${ }^{187} \mathrm{Os} /{ }^{188} \mathrm{Os}$ values are below the initial ${ }^{187} \mathrm{Os} /{ }^{188} \mathrm{Os}$ value $(\sim 1.0$; Levasseur et al., 1998) of modern normal seawater (Fig. 5), indicating that the precipitation of barites of the top part of the Liuchapo Formation was also likely influenced by the mixing of hydrothermal fluids. Moreover, the initial ${ }^{187} \mathrm{Os} /{ }^{188} \mathrm{Os}$ value of the top part of the Liuchapo Formation is more positive than that of the Member IV of the Doushantuo Formation, indicating more incorporation of radiogenic continent-derived Os into the precipitates. This phenomenon points to increased input of radiogenic Os due to enhanced continental weathering during the Ediacaran, likely ascribed to the convergence of West and East Gondwana at the time interval of 650-500 Ma (Sawaki et al., 2010). The interpretation is also supported by a corresponding increase of ${ }^{87} \mathrm{Sr} /{ }^{86} \mathrm{Sr}$ (e.g., Halverson and Shields-Zhou, 2011; Halverson et al., 2007).

\section{CONCLUSIONS}

(1) The Re-Os isochron ages of the top Liuchapo Formation and the Doushantuo Formation suggest that the Liuchapo Formation was likely deposited between 550 and $520 \mathrm{Ma}$.

(2) The large-scale mineralization of barite took place earlier than the development of the polymetallic Ni-Mo-PGE layer and V-enriched horizon; the timing offset likely resulted from differential elemental concentration related to certain local factors (i. e., hydrothermal fluids, seawater redox and biological activity).

(3) The hydrothermal mixing was likely involved in the precipitation of barites of the top Liuchapo Formation. More- 


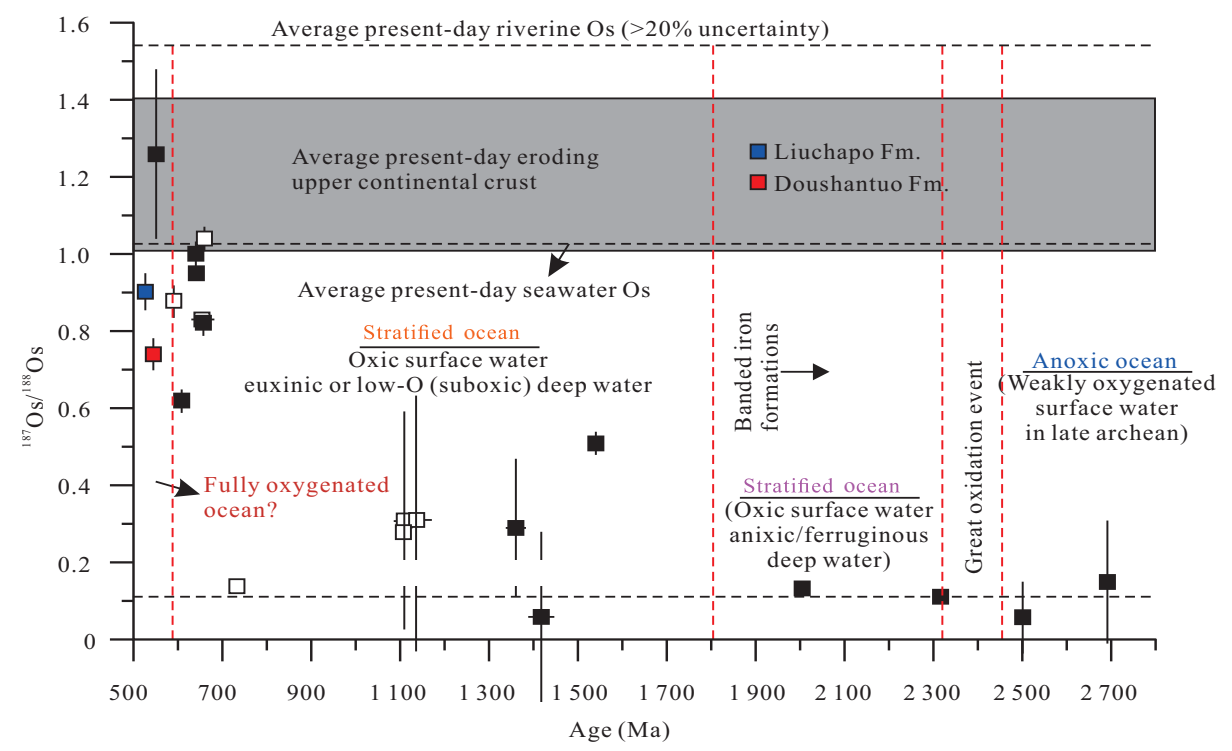

Figure 5. Initial ${ }^{187} \mathrm{Os} /{ }^{188} \mathrm{Os}$ values of the seawater evaluated from Re-Os isochron regressions of Precambrian organic-rich sedimentary rock and synsedimentaryearly diagenetic pyrite in organic-rich sedimentary rock. Data are compiled from Rooney et al. $(2011,2010)$ and Kendall et al. $(2009)$. Red square, from the upper part (Member IV) of the Doushantuo Formation; blue square, from the top part of the Liuchapo Formation.

over, the increase of initial ${ }^{187} \mathrm{Os} /{ }^{188} \mathrm{Os}$ values between the two study intervals was probably ascribed to gradual enhancement of continental weathering intensity and riverine flux during the continent uplift.

\section{ACKNOWLEDGMENTS}

This work was jointly supported by the National Natural Science Foundation of China (Nos. 41763006, 42063009, U1812402) and the Talent Base Project of Guizhou Province (No. RCJD2018-21). Thanks go to two anonymous reviewers for their useful comments to improve the original version of the manuscript. The final publication is available at Springer via https://doi.org/10.1007/s12583-021-1473-4.

Open Access: This article is licensed under a Creative Commons Attribution 4.0 International License, which permits use, sharing, adaptation, distribution and reproduction in any medium or format, as long as you give appropriate credit to the original author(s) and the source, provide a link to the Creative Commons licence, and indicate if changes were made. The images or other third party material in this article are included in the article's Creative Commons licence, unless indicated otherwise in a credit line to the material. If material is not included in the article's Creative Commons licence and your intended use is not permitted by statutory regulation or exceeds the permitted use, you will need to obtain permission directly from the copyright holder. To view a copy of this licence, visit http:// creativecommons.org/licenses/by/4.0/.

\section{REFERENCES CITED}

An, Z. H., Jiang, G. Q., Tong, J. N., et al., 2015. Stratigraphic Position of the Ediacaran Miaohe Biota and Its Constrains on the Age of the Upper Doushantuo $\delta^{13} \mathrm{C}$ Anomaly in the Yangtze Gorges Area, South China. Precambrian Research, 271: 243-253. https://doi.org/10.1016/j. precamres.2015.10.007

Charvet, J., 2013. The Neoproterozoic-Early Paleozoic Tectonic Evolution of the South China Block: An Overview. Journal of Asian Earth Sciences, 74: 198-209. https://doi.org/10.1016/j.jseaes.2013.02.015

Chen, C., Feng, Q., Gan, Z., 2020. Zircon U-Pb Ages and its Geological Significance of Tuffs between the Doushantuo and Liuchapo Formaion at Yangtou Section, Guizhou Province. Earth Science, 45(3): 880-891. https://doi.org/10.3799/dqkx.2019.103 (in Chinese with English Abstract)

Chen, D. Z., Wang, J. G., Qing, H. R., et al., 2009. Hydrothermal Venting Activities in the Early Cambrian, South China: Petrological, Geochronological and Stable Isotopic Constraints. Chemical Geology, 258(3/4): 168-181. https://doi.org/10.1016/j.chemgeo.2008.10.016

Chen, D. Z., Zhou, X. Q., Fu, Y., et al., 2015. New U-Pb Zircon Ages of the Ediacaran-Cambrian Boundary Strata in South China. Terra Nova, 27 (1): 62-68. https://doi.org/10.1111/ter.12134

Cohen, A. S., 2004. The rhenium-Osmium Isotope System: Applications to Geochronological and Palaeoenvironmental Problems. Journal of the Geological Society, 161(4): 729-734. https://doi.org/10.1144/0016764903-084

Cohen, A. S., Coe, A. L., Bartlett, J. M., et al., 1999. Precise Re-Os Ages of Organic-Rich Mudrocks and the Os Isotope Composition of Jurassic Seawater. Earth and Planetary Science Letters, 167(3/4): 159-173. https://doi.org/10.1016/s0012-821x(99)00026-6

Condon, D., Zhu, M. Y., Bowring, S., et al., 2005. U-Pb Ages from the Neoproterozoic Doushantuo Formation, China. Science, 308(5718): 95-98. https://doi.org/10.1126/science.1107765

Dickson, A. J., Cohen, A. S., Coe, A. L., et al., 2015. Evidence for Weathering and Volcanism during the PETM from Arctic Ocean and Peri-Tethys Osmium Isotope Records. Palaeogeography, Palaeoclimatology, Palaeoecology, 438: 300-307. https://doi.org/ 10.1016/j.palaeo.2015.08.019

Ding, Y., Chen, D. Z., Zhou, X. Q., et al., 2019. Tectono-Depositional Pattern and Evolution of the Middle Yangtze Platform (South China) during the Late Ediacaran. Precambrian Research, 333: 105426. https: //doi.org/10.1016/j.precamres.2019.105426

Du Vivier, A. D. C., Selby, D., Sageman, B. B., et al., 2014. Marine ${ }^{187} \mathrm{Os} /{ }^{188} \mathrm{Os}$ Isotope Stratigraphy Reveals the Interaction of Volcanism 
and Ocean Circulation during Oceanic Anoxic Event 2. Earth and Planetary Science Letters, 389: 23-33. https://doi.org/10.1016/j. eps1.2013.12.024

Erwin, D. H., Laflamme, M., Tweedt, S. M., et al., 2011. The Cambrian Conundrum: Early Divergence and Later Ecological Success in the Early History of Animals. Science, 334(6059): 1091-1097. https://doi. org/10.1126/science. 1206375

Feng, L. J., Li, C., Huang, J., et al., 2014. A Sulfate Control on Marine MidDepth Euxinia on the Early Cambrian (ca. 529-521 Ma) Yangtze Platform, South China. Precambrian Research, 246: 123-133. https:// doi.org/10.1016/j.precamres.2014.03.002

Finlay, A. J., Selby, D., Gröcke, D. R., 2010. Tracking the Hirnantian Glaciation Using Os Isotopes. Earth and Planetary Science Letters, 293(3/4): 339-348. https://doi.org/10.1016/j.eps1.2010.02.049

Fu, Y., Dong, L., Li, C., et al., 2016. New Re-Os Isotopic Constrains on the Formation of the Metalliferous Deposits of the Lower Cambrian Niutitang Formation. Journal of Earth Science, 27(2): 271-281. https:// doi.org/10.1007/s12583-016-0606-7

Halverson, G. P., Dudás, F. Ö., Maloof, A. C., et al., 2007. Evolution of the ${ }^{87} \mathrm{Sr} /{ }^{86} \mathrm{Sr}$ Composition of Neoproterozoic Seawater. Palaeogeography, Palaeoclimatology, Palaeoecology, 256(3/4): 103-129. https://doi.org/ 10.1016/j.palaeo.2007.02.028

Halverson, G. P., Shields-Zhou, G., 2011. Chapter 4 Chemostratigraphy and the Neoproterozoic Glaciations. In: Arnaud, E., Halverson, G. P., Shields-Zhou, G., eds., The Geological Record of Neoproterozoic Glaciations. Geological Society, London, Memoirs, 36(1): 51-66. https://doi.org/10.1144/m36.4

Han, T., Fan, H. F., Zhu, X. Q., et al., 2017. Submarine Hydrothermal Contribution for the Extreme Element Accumulation during the Early Cambrian, South China. Ore Geology Reviews, 86: 297-308. https:// doi.org/10.1016/j.oregeorev.2017.02.030

Hannah, J. L., Bekker, A., Stein, H. J., et al., 2004. Primitive Os and 2316 Ma Age for Marine Shale: Implications for Paleoproterozoic Glacial Events and the Rise of Atmospheric Oxygen. Earth and Planetary Science Letters, 225(1/2): 43-52. https://doi.org/10.1016/j. eps1.2004.06.013

Huang, T. Y., Chen, D. Z., Ding, Y., et al., 2020. SIMS U-Pb Zircon Geochronological and Carbon Isotope Chemostratigraphic Constraints on the Ediacaran-Cambrian Boundary Succession in the Three Gorges Area, South China. Journal of Earth Science, 31(1): 69-78. https://doi. org/10.1007/s12583-019-1233-x

Huang, T. Y., Chen, D. Z., Fu, Y., et al., 2019. Development and Evolution of a Euxinic Wedge on the Ferruginous Outer Shelf of the Early Cambrian Yangtze Sea. Chemical Geology, 524: 259-271. https://doi. org/10.1016/j.chemgeo.2019.06.024

Jenkins, R. J. F., Cooper, J. A., Compston, W., 2002. Age and Biostratigraphy of Early Cambrian Tuffs from SE Australia and Southern China. Journal of the Geological Society, 159(6): 645-658. https://doi.org/10.1144/0016-764901-127

Jiang, G. Q., Shi, X. Y., Zhang, S. H., et al., 2011. Stratigraphy and Paleogeography of the Ediacaran Doushantuo Formation (ca. 635-551 Ma) in South China. Gondwana Research, 19(4): 831-849. https://doi. org/10.1016/j.gr.2011.01.006

Jiang, G. Q., Sohl, L. E., Christie-Blick, N., 2003. Neoproterozoic Stratigraphic Comparison of the Lesser Himalaya (India) and Yangtze Block (South China): Paleogeographic Implications. Geology, 31(10): 917-920. https://doi.org/10.1130/g19790.1

Jiang, S. Y., Pi, D. H., Heubeck, C., et al., 2009. Early Cambrian Ocean
Anoxia in South China. Nature, 459(7248): E5-E6; Discussion E6. https://doi.org/10.1038/nature08048

Kendall, B., Creaser, R. A., Selby, D., 2006. Re-Os Geochronology of Postglacial Black Shales in Australia: Constraints on the Timing of "Sturtian" Glaciation. Geology, 34(9): 729-732. https://doi.org/ $10.1130 / \mathrm{g} 22775.1$

Kendall, B., Creaser, R. A., Selby, D., 2009 $\cdot{ }^{187} \operatorname{Re}-{ }^{187}$ Os Geochronology of Precambrian Organic-Rich Sedimentary Rocks. Geological Society, London, Special Publications, 326(1): 85-107. https://doi.org/10.1144/ $\operatorname{sp} 326.5$

Levasseur, S., Birck, J. L., Allègre, C. J., 1998. Direct Measurement of Femtomoles of Osmium and the ${ }^{187} \mathrm{Os} /{ }^{186} \mathrm{Os}$ Ratio in Seawater. Science, 282(5387): 272-274. https://doi.org/10.1126/science.282.5387.272

Levasseur, S., Birck, J. L., Allègre, C. J., 1999. The Osmium Riverine Flux and the Oceanic Mass Balance of Osmium. Earth and Planetary Science Letters, 174(1/2): 7-23. https://doi.org/10.1016/s0012-821x (99)00259-9

Li, C., Love, G. D., Lyons, T. W., et al., 2010a. A Stratified Redox Model for the Ediacaran Ocean. Science, 328(5974): 80-83. https://doi.org/ 10.1126/science. 1182369

Li, C., Qu, W. J., Zhou, L. M., et al., 2010b. Rapid Separation of Osmium by Direct Distillation with Carius Tube. Rock and Mineral Analysis, 29 (1): 14-16. https://doi.org/10.15898/j.cnki.11-2131/td.2010.01.001 (in Chinese with English Abstract)

Li, C., Shi, W., Cheng, M., et al., 2020. The Redox Structure of Ediacaran and Early Cambrian Oceans and Its Controls. Science Bulletin, 65(24): 2141-2149. https://doi.org/10.1016/j.scib.2020.09.023

Li, S. R., Xiao, Q. Y., Shen, J. F., et al., 2003. Rhenium-Osmium Isotope Constraints on the Age and Source of the Platinum Mineralization in the Lower Cambrian Black Rock Series of Hunan-Guizhou Provinces, China. Science in China Series D: Earth Sciences, 46(9): 919-927. https://doi.org/10.1360/01yd0277

Liu, Z. Q., Jiang, X. J., Li, C., et al., 2021. Metallogenic Age and Setting of Boka Gold Deposit Dongchuan: Evidence from Re-Os Isotope of Sulfide and Trace Element of Carbonaceous Slate. Earth Science, 46(12): 4260-4273. https://doi.org/10.3799/dqkx.2021.178 (in Chinese with English Abstract)

Liu, Z. Y., Selby, D., Zhang, H., et al., 2020. Evidence for Volcanism and Weathering during the Permian-Triassic Mass Extinction from Meishan (South China) Osmium Isotope Record. Palaeogeography, Palaeoclimatology, Palaeoecology, 553: 109790. https://doi.org/ 10.1016/j.palaeo.2020.109790

Mao, J. W., Lehmann, B., Du, A. D., et al., 2002. Re-Os Dating of Polymetallic Ni-Mo-PGE-Au Mineralization in Lower Cambrian Black Shales of South China and Its Geologic Significance. Economic Geology, 97(5): 1051-1061. https://doi.org/10.2113/gsecongeo.97.5.1051

Matsumoto, H., Kuroda, J., Coccioni, R., et al., 2020. Marine Os Isotopic Evidence for Multiple Volcanic Episodes during Cretaceous Oceanic Anoxic Event 1b. Scientific Reports, 10(1): 12601. https://doi.org/ 10.1038/s41598-020-69505-x

McDaniel, D. K., Walker, R. J., Hemming, S. R., et al., 2004. Sources of Osmium to the Modern Oceans: New Evidence from the ${ }^{190} \mathrm{Pt}-{ }^{186} \mathrm{Os}$ System. Geochimica et Cosmochimica Acta, 68(6): 1243-1252. https:// doi.org/10.1016/j.gca.2003.08.020

Oxburgh, R., 1998. Variations in the Osmium Isotope Composition of Sea Water over the Past 200000 Years. Earth and Planetary Science Letters, 159(3/4): 183-191. https://doi.org/10.1016/s0012-821x(98) 00057-0 
Peucker-Ehrenbrink, B., Ravizza, G., 2000. The Marine Osmium Isotope Record. Terra Nova, 12(5): 205-219. https://doi. org/10.1046/j. 13653121.2000.00295.x

Ravizza, G., Peucker-Ehrenbrink, B., 2003. Chemostratigraphic Evidence of Deccan Volcanism from the Marine Osmium Isotope Record. Science, 302(5649): 1392-1395. https://doi.org/10.1126/science.1089209

Rooney, A. D., Chew, D. M., Selby, D., 2011. Re-Os Geochronology of the Neoproterozoic-Cambrian Dalradian Supergroup of Scotland and Ireland: Implications for Neoproterozoic Stratigraphy, Glaciations and Re-Os Systematics. Precambrian Research, 185(3/4): 202-214. https:// doi.org/10.1016/j.precamres.2011.01.009

Rooney, A. D., Macdonald, F. A., Strauss, J. V., et al., 2014. Re-Os Geochronology and Coupled Os-Sr Isotope Constraints on the Sturtian Snowball Earth. Proceedings of the National Academy of Sciences of the United States of America, 111(1): 51-56. https://oi. org/10.1073/ pnas. 1317266110

Rooney, A. D., Selby, D., Houzay, J. P., et al., 2010. Re-Os Geochronology of a Mesoproterozoic Sedimentary Succession, Taoudeni Basin, Mauritania: Implications for Basin-Wide Correlations and Re-Os Organic-Rich Sediments Systematics. Earth and Planetary Science Letters, 289(3/4): 486-496. https://doi.org/10.1016/j.eps1.2009.11.039

Rotich, E. K., Handler, M. R., Naeher, S., et al., 2020. Re-Os Geochronology and Isotope Systematics, and Organic and Sulfur Geochemistry of the Middle-Late Paleocene Waipawa Formation, New Zealand: Insights into Early Paleogene Seawater Os Isotope Composition. Chemical Geology, 536: 119473. https://doi.org/10.1016/ j.chemgeo.2020.119473

Sawaki, Y., Ohno, T., Tahata, M., et al., 2010. The Ediacaran Radiogenic Sr Isotope Excursion in the Doushantuo Formation in the Three Gorges Area, South China. Precambrian Research, 176(1/2/3/4): 46-64. https: //doi.org/10.1016/j.precamres.2009.10.006

Sharma, M., Wasserburg, G. J., 1997. Osmium in the Rivers. Geochimica et Cosmochimica Acta, 61(24): 5411-5416. https://doi.org/10.1016/ s0016-7037(97)00329-3

Shi, C. H., Cao, J., Han, S. C., et al., 2021. A Review of Polymetallic Mineralization in Lower Cambrian Black Shales in South China: Combined Effects of Seawater, Hydrothermal Fluids, and Biological Activity. Palaeogeography, Palaeoclimatology, Palaeoecology, 561: 110073. https://doi.org/10.1016/j.palaeo.2020.110073

Stein, R., 1990. Organic Carbon Content/Sedimentation Rate Relationship and Its Paleoenvironmental Significance for Marine Sediments. GeoMarine Letters, 10(1): 37-44. https://doi.org/10.1007/bf02431020

Sun, P. C., Li, C., Zhou, L. M., et al., 2021. Dating Metallogenic Age of Jinding $\mathrm{Pb}-\mathrm{Zn}$ Deposit in Yunnan: Evidence from Re-Os Isotope of Bitumen. Earth Science, 46(12):. 4247-4259. https://oi.org/10.3799/ dqkx.2021.085

Tripathy, G. R., Singh, S. K., 2015. Re-Os Depositional Age for Black Shales from the Kaimur Group, Upper Vindhyan, India. Chemical Geology, 413: 63-72. https://doi.org/10.1016/j.chemgeo.2015.08.011

Turgeon, S. C., Creaser, R. A., Algeo, T. J., 2007. Re-Os Depositional Ages and Seawater Os Estimates for the Frasnian-Famennian Boundary: Implications for Weathering Rates, Land Plant Evolution, and Extinction Mechanisms. Earth and Planetary Science Letters, 261(3/4): 649-661. https://doi.org/10.1016/j.eps1.2007.07.031

Wang, J., Li, Z. X., 2003. History of Neoproterozoic Rift Basins in South China: Implications for Rodinia Break-up. Precambrian Research, 122 (1/2/3/4): 141-158. https://doi.org/10.1016/s0301-9268(02)00209-7

Wang, W., Zhou, M. Z., Chu, Z. Y., et al., 2020. Constraints on the
Ediacaran-Cambrian Boundary in Deep-Water Realm in South China: Evidence from Zircon CA-ID-TIMS U-Pb Ages from the Topmost Liuchapo Formation. Science China Earth Sciences, 63(8): 11761187. https://doi.org/10.1007/s11430-019-9590-0

Wang, X. Q., Shi, X. Y., Jiang, G. Q., et al., 2012. New U-Pb Age from the Basal Niutitang Formation in South China: Implications for Diachronous Development and Condensation of Stratigraphic Units across the Yangtze Platform at the Ediacaran-Cambrian Transition. Journal of Asian Earth Sciences, 48: 1-8. https://doi.org/10.1016/j. jseaes.2011.12.023

Wang, Y., Huang, Z. Q., Chen, H. D., et al., 2012. Stratigraphical Correlation of the Liuchapo Formation with the Dengying Formation in South China. Journal of Jilin University (Earth Science Edition), 42(S1): 328-335. https://doi. org/10.13278/j. cnki. jjuese. 2012. s1.049 (in Chinese with English Abstract)

Wei, S. C., Fu, Y., Liang, H. P., et al., 2018. Re-Os Geochronology of the Cambrian Stage-2 and -3 Boundary in Zhijin County, Guizhou Province, China. Acta Geochimica, 37(2): 323-333. https://doi.org/ 10.1007/s11631-017-0228-5

Xu, L. G., Lehmann, B., Mao, J. W., et al., 2011. Re-Os Age of Polymetallic Ni-Mo-PGE-Au Mineralization in Early Cambrian Black Shales of South China-A Reassessment. Economic Geology, 106(3): 511-522. https://doi.org/10.2113/econgeo.106.3.511

Yamashita, Y., Takahashi, Y., Haba, H., et al., 2007. Comparison of Reductive Accumulation of Re and Os in Seawater-Sediment Systems. Geochimica et Cosmochimica Acta, 71(14): 3458-3475. https://doi.org/ 10.1016/j.gca.2007.05.003

Yang, C., Zhu, M. Y., Condon, D. J., et al., 2017. Geochronological Constraints on Stratigraphic Correlation and Oceanic Oxygenation in Ediacaran-Cambrian Transition in South China. Journal of Asian Earth Sciences, 140: 75-81. https://doi.org/10.1016/j.jseaes.2017.03.017

Yang, G., Hannah, J. L., Zimmerman, A., et al., 2009. Re-Os Depositional Age for Archean Carbonaceous Slates from the Southwestern Superior Province: Challenges and Insights. Earth and Planetary Science Letters, 280(1/2/3/4): 83-92. https://doi.org/10.1016/j.eps1.2009.01.019

Zhao, G. C., Wang, Y. J., Huang, B. C., et al., 2018. Geological Reconstructions of the East Asian Blocks: From the Breakup of Rodinia to the Assembly of Pangea. Earth-Science Reviews, 186: 262286. https://doi.org/10.1016/j.earscirev.2018.10.003

Zhou, C. M., Yuan, X. L., Xiao, S. H., et al., 2019. Ediacaran Integrative Stratigraphy and Timescale of China. Science China Earth Sciences, 62(1): 7-24. https://doi.org/10.1007/s11430-017-9216-2

Zhou, M. Z., Luo, T. Y., Huff, W. D., et al., 2018. Timing the Termination of the Doushantuo Negative Carbon Isotope Excursion: Evidence from U$\mathrm{Pb}$ Ages from the Dengying and Liuchapo Formations, South China. Science Bulletin, 63(21): 1431-1438. https://doi.org/10.1016/j.scib. 2018.10.002

Zhu, B., Becker, H., Jiang, S. Y., et al., 2013. Re-Os Geochronology of Black Shales from the Neoproterozoic Doushantuo Formation, Yangtze Platform, South China. Precambrian Research, 225: 67-76. https://doi. org/10.1016/j.precamres.2012.02.002

Zhu, M. Y., Yang, A. H., Yuan, J. L., et al., 2019. Cambrian Integrative Stratigraphy and Timescale of China. Science China Earth Sciences, 62(1): 25-60. https://doi.org/10.1007/s11430-017-9291-0

Zhu, M., Zhuravlev, A. Y., Wood, R. A., et al., 2017. A Deep Root for the Cambrian Explosion: Implications of New Bio- and Chemostratigraphy from the Siberian Platform. Geology, 45(5): 459462. https://doi.org/10.1130/g38865.1 